\title{
Dental Gemination in the Inferior Canine in Both Dentition. Case Report
}

\author{
Geminación Dental en Canino Inferior en Ambas Denticiones. Reporte de Caso
}

\author{
"Nilton Alves; **Carlos Manuel de Oliveira Nascimento \& ${ }^{* * * *}$ Juvenal João Patriarca
}

\begin{abstract}
ALVES, N.; NASCIMENTO, C. M. O. \& PATRIARCA, J. J. Dental Gemination in the inferior canine in both dentition. Case report. Int. J. Morphol., 28(3):873-874, 2010.

SUMMARY: Geminate teeth are anomalies arising from the attempt of the division of a only one germ, characterized by invagination and resulting in incomplete formation of two teeth. In general, it presents two crowns, totally or partially separated, with one root and one root canal. Female patient, 8 years old, Asian descent (Chinese), attended a private clinic (Odemira Dental Clinic) in Odemira, Portugal, for a routine consult. At intraoral clinical examination differentiated coronary anatomy, of the tooth 83 was found, with the presence of a bifid crown in which there was a central groove that came from the cemento-enamel junction. The radiographic exam revealed the presence of only one wide root canal, and two separate pulp cavities, each one corresponding to a portion of the bifid crown. There was also, its permanent successor, with similar radiographic features In our case we could observe the alteration in the inferior canine of both dentition with a bifid crown and radiographically only one root as well as only one root canal with two pulp cavities.
\end{abstract}

KEY WORDS: Dental gemination; Inferior canine; Radiographic anatomy; Bifid crown.

\section{INTRODUCTION}

Geminate teeth are anomalies arising from the attempt of the division of a only one germ, characterized by invagination and resulting in incomplete formation of two teeth. In general, presents two crowns, totally or partially separated, with one root and one root canal (Shafer et al., 1987).

In most cases occur in the primary dentition (Tavano, 1977, Araújo \& Araújo, 1984, Pereira et al., 2000). According Pereira et al. the incisives are the most affected, presenting, usually, incomplete division, which shows a large crown, only one root and only one root canal. According Araújo \& Araújo and Coleman \& Nelson (1996) the crown is duplicate or bifid with a groove that runs from the incisal margin to the cervical region.

\section{CASE REPORT}

Female patient, 8 years old, asian descent (chinese), attended in a private clinic (Odemira Dental Clinic) in Odemira,
Portugal, for a routine consult. At intraoral clinical examination was found differentiated coronary anatomy, of the tooth 83 , with the presence of a bifid crown in which there was a central groove that came from the cemento-enamel junction (Fig. 1A)

The radiographic exam revealed the presence of only one root canal, wide, and two separate pulp cavities, each one corresponding to a portion of the bifid crown. There was also, its permanent successor, with similar radiographic features (Fig. 1B).

\section{DISCUSSION}

Ferraz et al. (2001) and Neville et al. (2004) affirm that the dental gemination is a morphological alteration that sometimes is confused with fusion, but radiographically the gemination shows only one root canal with a wide pulp cavity. According Freitas et al. (1988) and Tavano the dental gemination shows only one root canal and two pulp cavities,

* Departamento de Ciencias Básicas, Facultad de Ciencias de la Salud, Universidad de Talca, Chile.

** Médico Dentista, M.Sc., Clínica Dentária Odemira, Odemira, Portugal.

**** Médico Dentista, Clínica Dentária Odemira, Odemira, Portugal. 
while in the fusion there are two roots canals and two dental roots. In our case we could observe a bifid crown and radiographically only one root as well as only one root canal with a two pulp cavity.

Nik-Hussein \& Abdul Majid (1996) and Balarotti (2003) affirm that dental anomalies present in deciduous dentition are associated with their permanent successors, which was a fact observed in our case. We agree with these authors when they affirm that knowledge of these variations help the dental surgeons in the clinical treatment. Barbosa et al. (2005) affirm that the more affected teeth are the lateral superior incisive, inferior premolars and superior molars. Tommasi (1989) affirms that the more affected teeth are the inferior incisive. In our case we could observe the alteration in the inferior canine of both dentition.

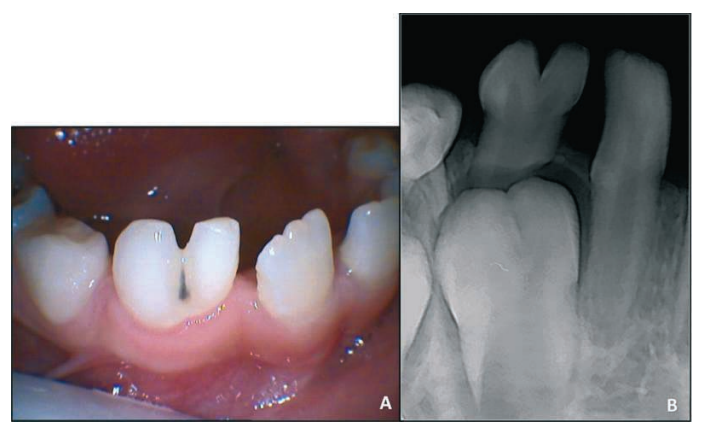

Fig. 1. (A) Tooth 83 with a bifid crown in which there is a central groove that came from the cemento-enamel junction; (B) Periapical radiography showing the presence of only one root canal, wide, and two separate pulp cavities, each one corresponding to a portion of the bifid crown. The radiographic exam reveals also, his permanent successor, with similar radiographic features.

ALVES, N.; NASCIMENTO, C. M. O. \& PATRIARCA, J. J. Geminación dental en canino inferior en ambas denticiones - Reporte de caso.Int. J. Morphol., 28(3):873-874, 2010.

RESUMEN: Los dientes geminados son anomalías derivadas del intento de división de un solo germen, que se caracteriza por la invaginación y provoca la formación incompleta de dos dientes. En general, el diente presenta dos coronas, total o parcialmente separadas, con una sola raíz y un conducto radicular. Paciente mujer de 8 años de edad, ascendencia asiática (China), asistió a una clínica privada (Clínica Dental Odemira) en Odemira, Portugal, por una consulta de rutina. Al examen clínico intraoral se encontró una diferencia anatómica coronaria, del diente 8.3, con la presencia de una corona bífida en la cual había un surco central desde la unión cemento-esmalte. El examen radiográfico reveló la presencia de un solo conducto radicular, ancho, y dos cavidades pulpares separadas, cada una correspondiente a una parte de la corona bífida. Además se encontró su sucesor permanente, con similares características radiológicas. En nuestro caso, pudimos observar la alteración en el canino inferior de la dentición, tanto con una corona bífida y una sola raíz radiográficamente, así como un solo canal de la raíz con dos cavidades pulpares.

PALABRAS CLAVE: Geminación dental; Canino inferior; Anatomía radiográfica; Corona bífida.

\section{REFERENCES}

Araújo, N. S. \& Araújo, V. C. Patologia Bucal. São Paulo, Artes Médicas, 1984.

Balarotti, E. Estudo da prevalência de fusão e geminação na dentição decídua e possível correlação com anomalias na dentição permanente. Tese Mestrado, Universidade de São Paulo, 2003.

Barbosa, C. K. R.; Lopes, L. D.; Freitas, P. H. R.; Borges, P. G.; Silva, R. F. C.; Cunha, M. S. \& Scelza, M. F. Z. Morfological in the pulpar chamber that can interfere in the endodontic treatment. UFES Rev. Odontol., 7(2):47-51, 2005.

Coleman, G. C. \& Nelson, J. F. Princípios de diagnóstico bucal. Rio de Janeiro, Ed. Guanabara Koogan, 1996.

Ferraz, J. A.; de Carvalho Júnior, J. R.; Saquy, P. C.; Pécora, J. D. \& Sousa-Neto, M. D. Dental anomaly: dens evaginatus (talon cusp). Braz. Dent. J., 12(2):132-4, 2001.

Freitas, A.; Rosa, J. E. \& Souza, I. F. Radiologia Odontológica. $2^{\mathrm{a}}$. Ed. São Paulo, Ed. Artes Médicas, 1988.

Neville, B. W.; Damm, D. D.; Allen, C. M. \& Bouquot, J. E. Patologia Oral e Maxilofacial. $2^{\text {a }}$ Ed. Rio de Janeiro, Guabara Koogan, 2004.
Nik-Hussein, N. N. \& Abdul Majid, Z. Dental anomalies in the primary dentition: distribution and correlation with the permanent dentition. J. Clin. Pediatr. Dent., 21(1):15-9, 1996.

Pereira, A. J. A.; Fidel, R. A. S.; Fidel, S. R. Maxillary Lateral Incisor With Two Root Canals: fusion, gemination or dens invaginatus. Braz. Dent. J., 11(2):141-6, 2000.

Shafer, W. G.; Hine, M. K. \& Levy, B. M. Tratado de Patologia

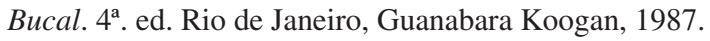

Tavano, O. Radiographic aspects of dental anomalies of the maxillomandibular complex. $11^{\text {th }}$ lecture. Ars curandi em Odontologia, 4(3):47-59, 1977.

Tommasi, A. F. Diagnóstico em Patologia Bucal. $2^{\text {a }}$ Ed. São. Paulo, Pancast, 1989.

Correspondence to:

Nilton Alves

Facultad de Ciencias de la Salud

Universidad de Talca

Avenida Lircay s/n

Received: 06-03-2010

Talca - CHILE

Accepted: 07-04-2010

Email: niltonnalves@yahoo.com.br 